Miami Nature Biotechnology Short Reports

TheScientificWorld (2001) 1 (S3), 123SR

ISSN 1532-2246; DOI 10.1100/tsw.2001.216

\title{
IDENTIFICATION AND SEQUENCING OF BCL AND APAF1 GENES IN THE COMMON CARP, Cyprinus carpio
}

\author{
C. Chakravarthy*, G.T. Williams, D. Hoole \\ School of Life Sciences, Huxley Building, Keele University, Staffordshire ST5 5BG U.K. \\ * c.chakravarthy@biol.keele.ac.u
}

INTRODUCTION. The role of apoptosis in the immune system is being studied in cultured carp, Cyprinus carpio an economically important farmed fish. In intensive culturing systems, stress is suspected of reducing the immune competence of farm animals. Our initial studies investigated the effect of dexamethasone, a corticosteroid analogue, on the different immunocompetent cells in the pronephros and thymus. This is currently being extended to identify and sequence an apoptotic regulator (Bcl-x) and an apoptotic activator gene (APAF1) from the carp cDNA library.

METHOD. Cells from the pronephros and thymus were maintained in vitro, in L-15 medium (Sigma) supplemented with $2 \mathrm{mM} \mathrm{L-} \mathrm{glutamine} \mathrm{and} \mathrm{containing} \mathrm{penicillin} \mathrm{(100i.u./ml),}$ streptomycin $(100 \mu \mathrm{g} / \mathrm{ml})$, and $5 \%$ heat- inactivated foetal calf serum, at $20^{\circ} \mathrm{C}$. They were then exposed to different concentrations of dexamethasone $\left(0.1 \mu \mathrm{M}\right.$ to $\left.10.0 \mu \mathrm{M}^{2}\right)$ for up to $48 \mathrm{~h}$ in time. Control cells were those maintained in the culture medium lacking in dexamethasone. Cell viability and percentage of apoptotic cell death at times $0 \mathrm{~h}, 24 \mathrm{~h}$ and $48 \mathrm{~h}$ were determined using nigrosine dye exclusion and acridine orange stain respectively. DNA from approximately $10^{6}$ cells was isolated from each of the above samples and subjected to agarose gel electrophoresis.

In the differential experiment, the different types of immunocompetent cells were labelled with monoclonal antibodies WCI04, WCI09 and WCI12 and their responses to $1.0 \mu \mathrm{M}$ dexamethasone over 6 hours was recorded.

Degenerate primers for the Bcl-xL equivalent in carp were designed following a homology study on the sequences of Homo sapiens (human) and Xenopus laevis (South African clawed frog). The homology between human APAF1 and that of Danio rerio (Zebrafish) was examined, and primers constructed, for the comparable sequence in the carp. These were used in PCR to obtain sequences from the carp cDNA library. The sequences obtained will now be used as probes to sequence the rest of the gene(s).

RESULTS. Statistical analysis reveals that there is a significant difference between the number of control cells undergoing apoptotic cell death and that of cells exposed to the different concentrations of dexamethasone $(p<0.001)$ (Fig.1). This effect is greatest between the $0 \mathrm{~h}$ and $24 \mathrm{~h}$ time periods and appears to decrease after this time period, and is similar in the pronephros and the thymus. 


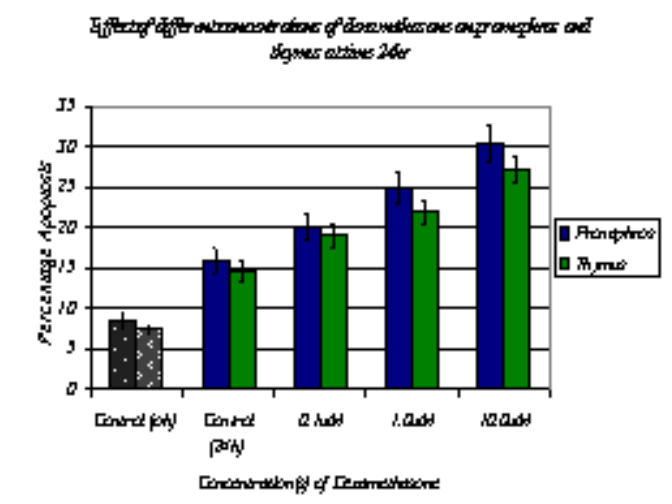

Figurel Graph showing the effect of apoptosis at 2 th after exposure to dexamethasone

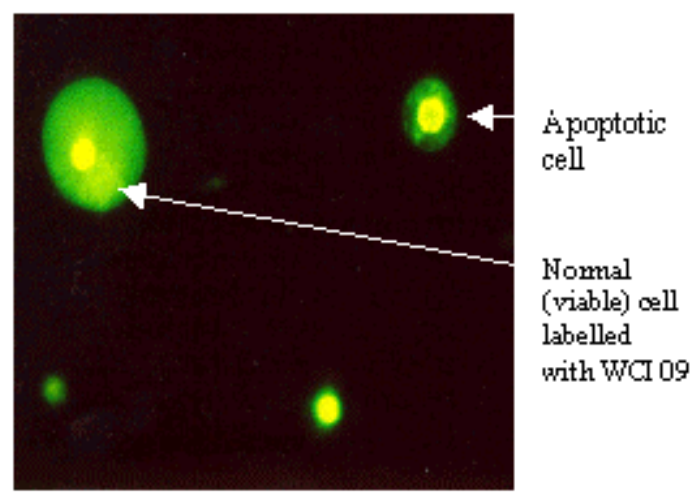

Figure 2 Cells stamed with acridine orange

Studies using monoclonal antibodies that recognised various surface components of carp leukocytes revealed that the thymocytes are more susceptible to apoptotic death induced by dexamethasone, when compared to the B-cells.

The initial sequence obtained from the carp cDNA library suggests that the isolate has a close homology to the zebrafish APAF1. Results of the Bcl-xL gene are swaited.

DISCUSSION. Dexamethasone is an analogue of cortisol, a stress hormone that is known to induce apoptosis. These studies have established the fact that dexamethasone induces apoptosis in the immune cells of pronephros and thymus and also that the response is differential, in the various cells. When the complete gene sequences are confirmed, the effect of cortisol on the expression of Bcl-x and APAF1 will be ascertained. This would lead to an understanding of how the stress hormone affects the primary response of the immune system ${ }^{1}$ at the genetic level.

ACKNOWLEDGEMENT. The monoclonal antibodies were kindly given to us by Dr. J. Rombout, Wanginghen University.

\section{REFERENCES.}

1. Clem, L.W., Bly, J.E., Ellaesser, C.F., Lobb, C.J., and Miller, N.W. (1990) J. Exp. Zool. 4, 123-125

2. Unpublished results of B. Swain, D. Hoole, and G.T. Williams, School of Life Sciences, Keele University, U.K. 

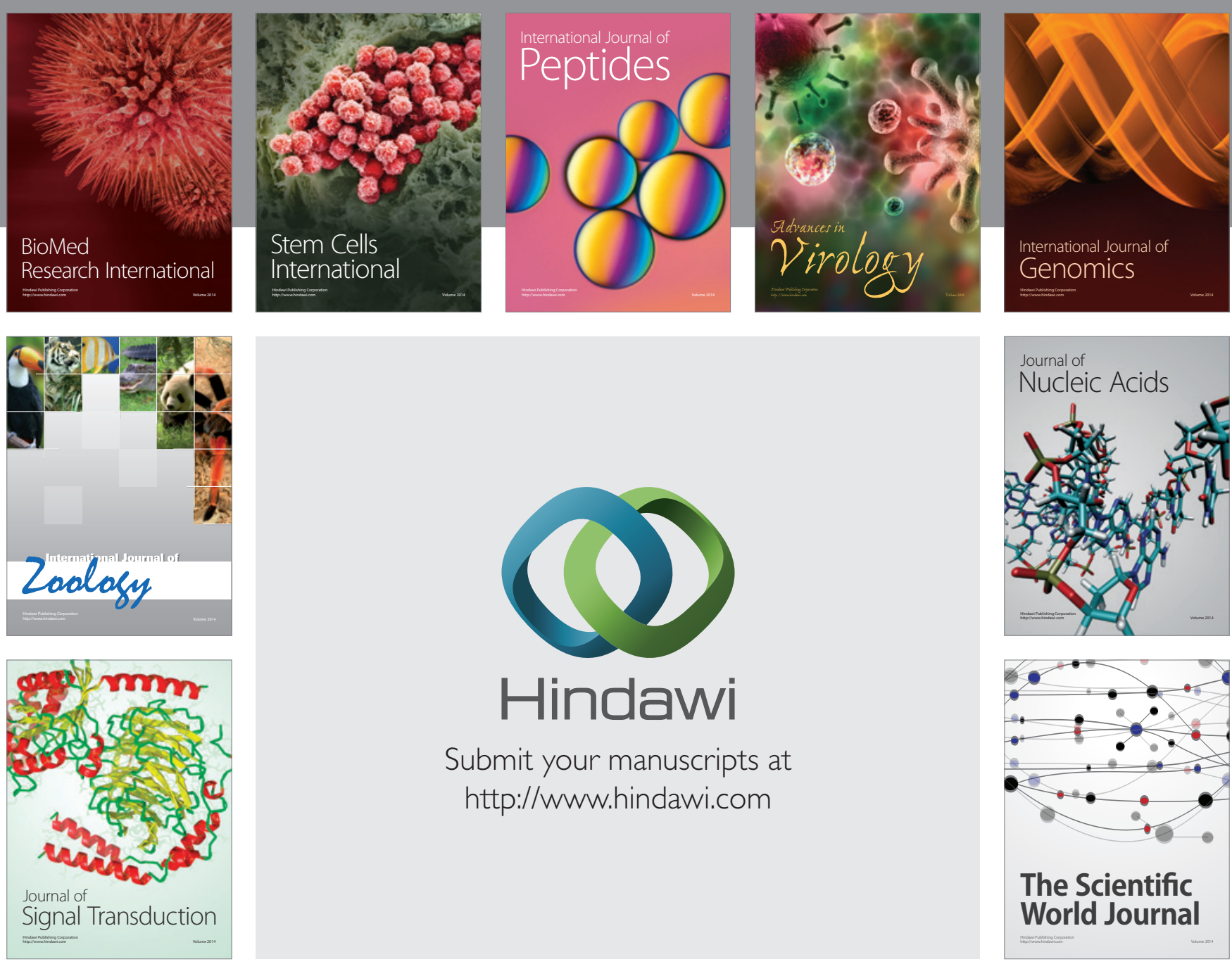

Submit your manuscripts at

http://www.hindawi.com
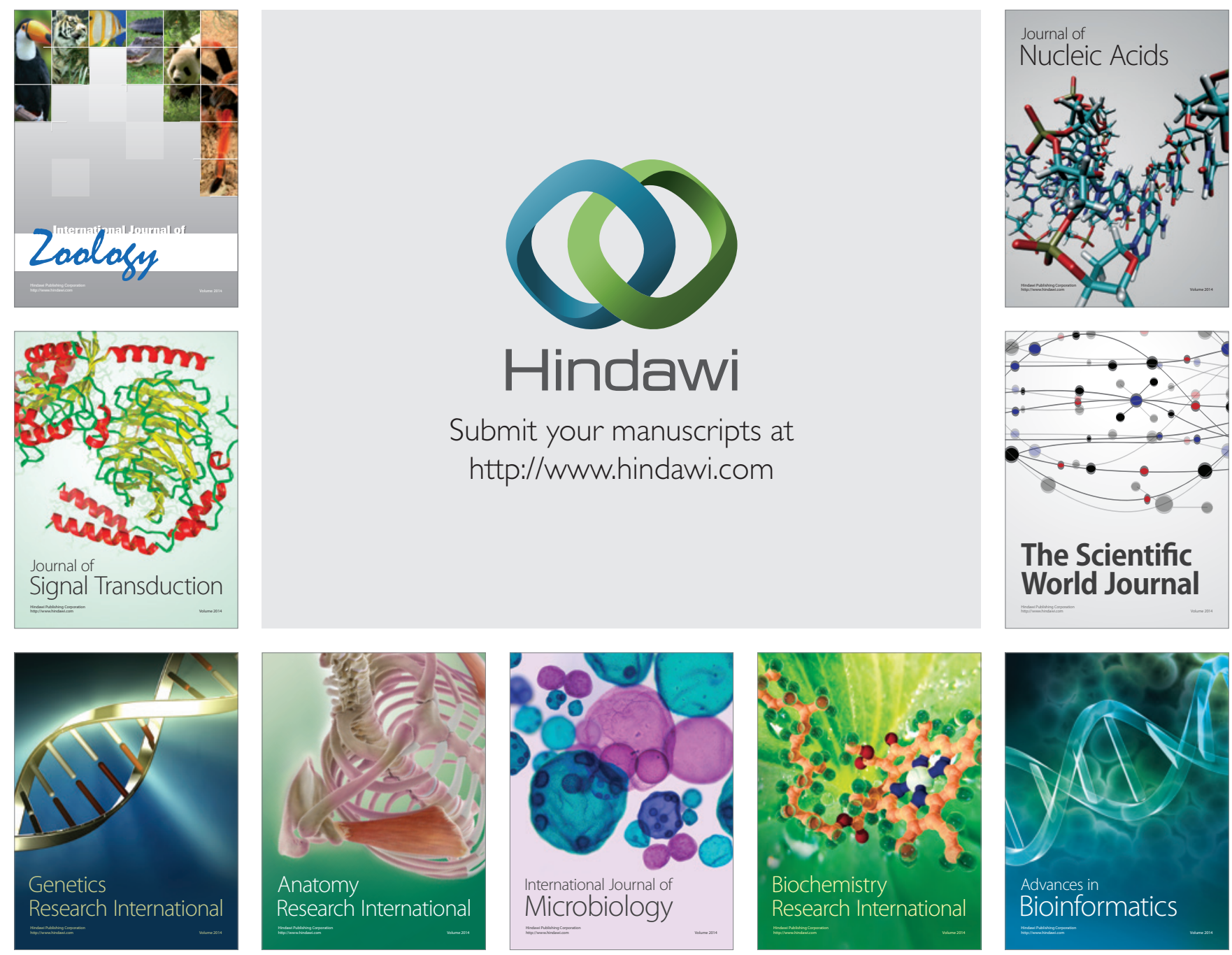

The Scientific World Journal
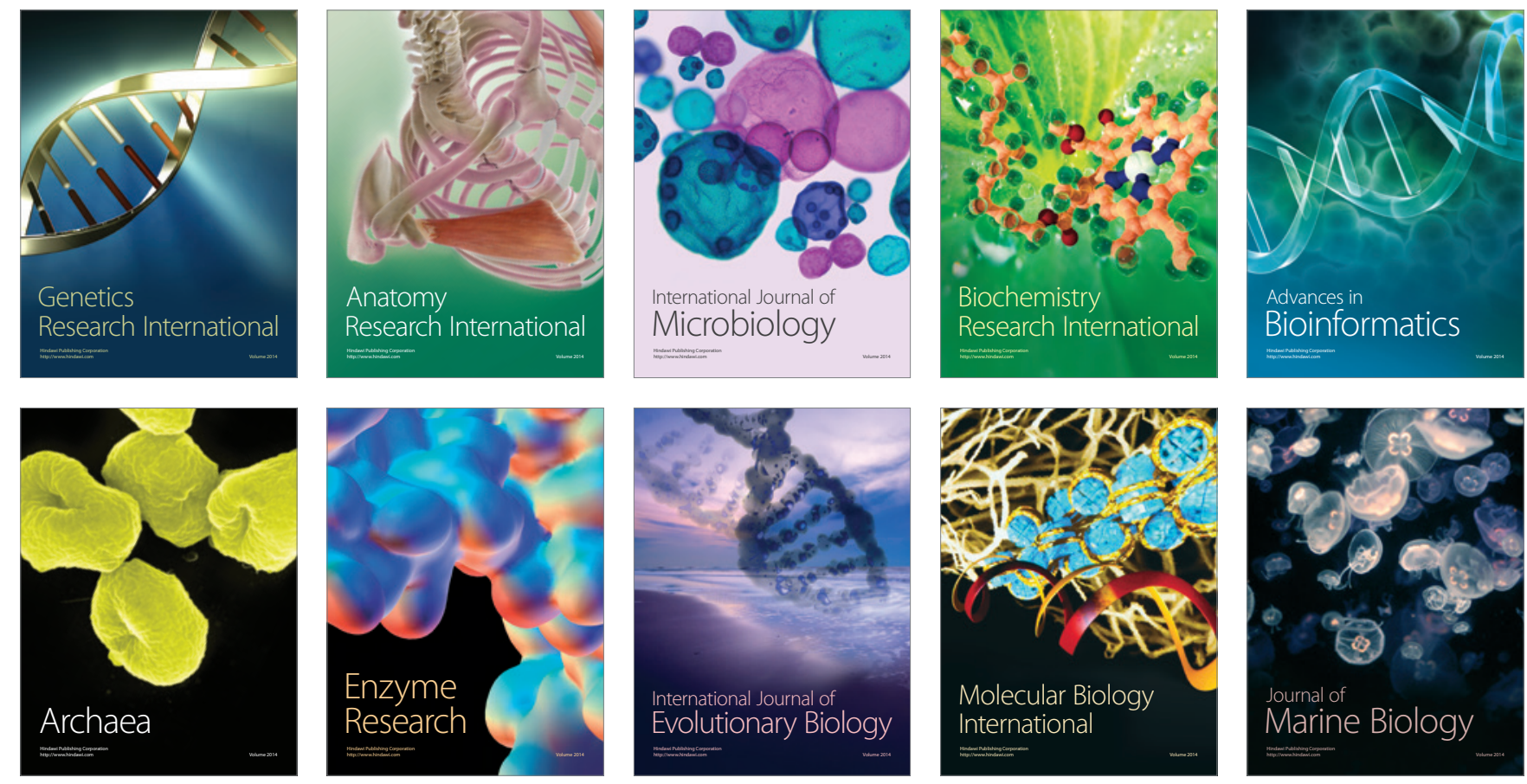